
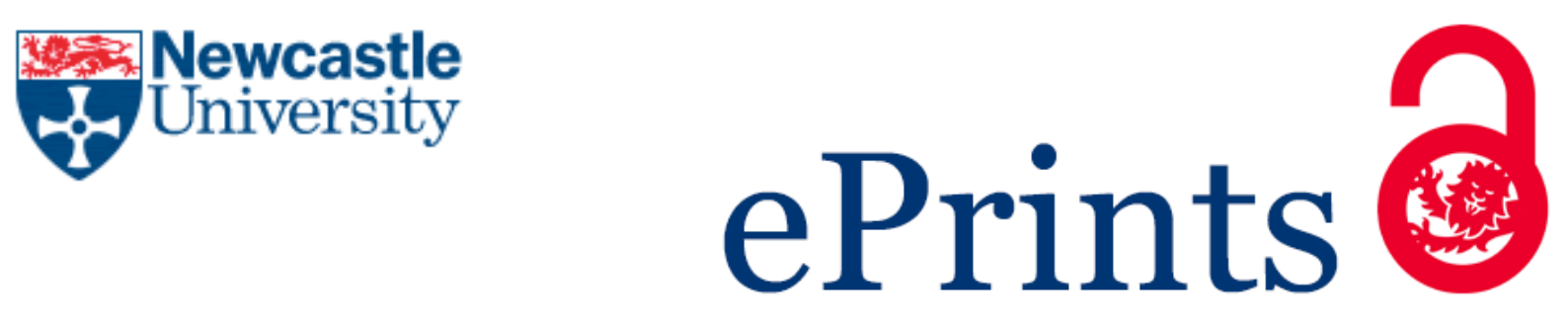

Dale M, Luck B, Fowler HJ, Blenkinsop S, Gill E, Bennett J, Kendon EJ, Chan

SC.

New climate change rainfall estimates for sustainable drainage.

Proceedings of the Institution of Civil Engineers - Engineering

Sustainability 2015,

http://dx.doi.org/10.1680/jensu.15.00030.

Copyright:

Copyright 2015 ICE Publishing. This article may be downloaded for personal use only. Any other use requires prior permission of the author and the ICE Publishing.

DOI link to article:

http://dx.doi.org/10.1680/jensu.15.00030

Date deposited:

$20 / 06 / 2017$

Embargo release date:

30 October 2016 


\section{New climate change rainfall estimates for sustainable drainage}

Murray Dale BSc, MSc (Eng), FRMetS, CMet

Senior Technologist/Hydrometeorologist, CH2M, Exeter, UK

Barry Luck BEng, CEng, MICE

Project Manager, UK Water Industry Research, London, UK

Hayley J. Fowler BA, MA, MSc, PhD

Professor of Climate Change Impacts, Newcastle University, Newcastle upon Tyne, UK

Stephen Blenkinsop BSc, MSc, PhD

Senior Research Associate, Newcastle University, Newcastle upon Tyne, UK
Elliot Gill BSC

Technical Director, CH2M, Exeter, UK

Jemma Bennett BSc, MSC

Water Engineer, $\mathrm{CH} 2 \mathrm{M}$, Exeter, UK

Elizabeth Kendon BA, MA, MSc, PhD

Senior Climate Extremes Scientist, Met Office Hadley Centre, Exeter, UK

Steven Chan BA, MSc, PhD

Research Associate, Newcastle University, Newcastle upon Tyne, UK

Sewer flooding, urban surface water flooding and wet weather pollution are recognised as significant problems in the UK and elsewhere in the world, and changes in extreme rainfall arising as a consequence of climate change are likely to exacerbate these problems. This paper reports on new approaches to estimate potential future rainfall intensity changes over the UK at temporal and spatial scales that impact on urban drainage systems. The research (part of UK Water Industry Research's programme of climate change related projects) has produced estimates of rainfall intensity change over different parts of the UK using a climate analogue approach and a very high-resolution (1.5 km) climate model developed by the UK Met Office. The new estimates produced are, in general, higher than existing UK climate change allowances for rainfall intensity. Sewer flooding volumes, flooding frequency and frequency of pollution events are also investigated for one location; indicating that these incidents and flood volumes are also likely to increase in the future.

\section{Introduction}

Sewer flooding, urban surface water flooding and wet weather pollution are already recognised as significant issues in the UK and elsewhere in the world, and climate change impacts on rainfall will likely exacerbate these problems (Arnbjerg-Nielsen et al., 2013; Ashley et al., 2005, 2007; Berggren, 2014; Mott Macdonald, 2011). UK Water Industry Research (UKWIR) has been commissioning research on this topic since 2001 and projects have made use of available climate projections from regional climate models (UKWIR, 2003, 2011). For the UK, probabilistic projections of climate change in the UK climate projections of 2009 (UKCP09; Murphy et al., 2009) give some indication of the expected changes in future UK precipitation, including a likely increase in precipitation extremes in winter but greater uncertainty as to the nature of changes in summer extremes. Building on this work, the Met Office (2010) produced a report for Ofwat, the UK water services regulation authority, which estimated future daily rainfall return periods for England and Wales. This study concluded that while winter rainfall events are projected to become more frequent, there was found to be "no clear signal for the change in frequency of summer rainfall events'. Using UKCP09 data, Mott Macdonald (2011), in a report for Ofwat, found that the median increase in 1 in 10 year flooding volume across 97 sewer catchments was $27 \%$ compared with current flooding (50th percentile of the probability distribution, medium emissions). Yet, the report acknowledged that this finding excluded the impact of 'summer convective storms'. Hence the estimate of $27 \%$ flooding volume increase could significantly underestimate the true impact.

It has long been known that climate models are relatively poor at simulating precipitation extremes (Flato et al., 2013), and regional climate models have been noted to have limited skill in the simulation of UK summer rainfall extremes on both daily and sub-daily timescales (Chan et al., 2014a; Fowler and Ekström, 2009). This is primarily associated with inadequate representation of important processes, such as convection, due to their relatively coarse resolution.

The majority of high-intensity, convective rainfall events occur in the months of May to September in the UK (Blenkinsop et al., 2015; Hand, 2002). Davies (2010) showed that, in the UK, there were 25 occasions when more than $20 \mathrm{~mm}$ of rainfall fell in $1 \mathrm{~h}$ during May to August at two or more Met Office rain gauges during the years 2000 to 2007, and only one occasion when this occurred outside these months. In summer 2007, 55000 properties were flooded as a result of intense summer rainfall, and the UK saw the largest loss of essential services since World War II, with almost half a million people without mains water or electricity (Cabinet Office, 2008). In summer 2012, $50 \mathrm{~mm}$ of rainfall in $2 \mathrm{~h}$ 
over Newcastle resulted in 300 properties being flooded (Smith et al., 2015). This tendency for high-intensity rainfall to occur in summer is also recognised in northwest Europe by Hanel and Buishand (2010), who found that most heavy precipitation occurs in summer in the Dutch portion of the Rhine basin.

The importance of intense convective rainfall in flood and pollution response, coupled with current uncertainties in model projections of these events, were key reasons for UKWIR to commission a project in 2014 to estimate potential future rainfall intensity changes over the UK at temporal and spatial scales that impact on urban drainage systems. This project (UKWIR, 2015) has produced estimates of rainfall intensity change at hourly timescales over different parts of the UK using two approaches that are specifically designed to capture changes in convective rainfall intensities

method 1: using rainfall data from other locations that currently experience a similar climate to that projected in the future for the location in question - a climate analogue approach

method 2: using outputs from a state-of-the-art, very highresolution climate model at resolutions designed to represent convective rainfall explicitly - a dynamic climate modelling approach.

Further information about these two approaches and findings of the research are provided below. Information from the rainfall intensity change estimates has also been used to examine the potential impacts on the urban drainage environment.

\section{Method - deriving future rainfall estimates}

\subsection{Climate analogue approach}

It has been hypothesised (Trenberth et al., 2003) that global temperature changes (due to climate change and variability) would lead to changes in precipitation intensities. The theoretical basis behind this proposition is that if relative humidity during wet days is not sensitive to temperature changes, atmospheric humidity will increase at a rate that follows the saturation vapour pressure dependency on temperature according to the physical relationship given by the Clausius-Clapeyron relation (this represents a scaling of extreme rainfall of approximately $7 \%$ per degree $\mathrm{K}$ ). Several studies have since demonstrated this scaling between extreme precipitation intensities and temperature on daily and sub-daily timescales (e.g. Hardwick Jones et al., 2010; Lenderink and van Meijgaard, 2008; Utsumi et al., 2011), and recent evidence has indicated a Clausius-Clapeyron relationship for UK summer sub-daily intense precipitation (Blenkinsop et al., 2015).

However, consistent evidence from empirical studies suggests greater complexity in the observed relationship between temperature and precipitation, with higher scaling for the most extreme precipitation events and negative scaling at higher temperatures $\left(>\sim 21^{\circ} \mathrm{C}\right.$, depending on region). For the UK,
Blenkinsop et al. (2015) have also shown a dependency of the scaling on the large-scale circulation type.

Nonetheless, the underlying principle of the Clausius-Clapeyron relationship and associated empirical evidence demonstrates that temperature change is a significant driver of changes in rainfall intensity. The present authors have therefore used this evidence as a basis to derive estimates of precipitation intensity change using an analogue rain gauge approach (method 1 in Section 1). Changes in intense rainfall have been estimated for four UK locations: London, Newcastle, Glasgow and Cardiff. These locations were selected as they are regionally disparate, experience different climatic characteristics, and there are urban drainage models that can be used for modelling impacts of the changes in rainfall intensity at each location. 'Reference' rain gauges providing hourly precipitation data, and considered representative of each location, were identified for the 'historic' period of 1981-2010 (data from Blenkinsop et al. (2015)). UKCP09 climate change projections (Murphy et al., 2009) were then used to identify the projected changes in mean summer temperature (JJA - June, July, August) for the four representative cities for the 2030s, 2050s and 2080s, based on the Special Report on Emission Scenarios high emissions scenario (A1F1; IPCC, 2000). The relevant UKCP09 regional climate model (RCM) grid cells ( $25 \mathrm{~km}$ grid) were identified for each city and the corresponding summer temperature projections obtained using the 50th percentile from the probabilistic projections.

These projections were then used to identify contemporary climatological analogues with similar mean summer temperatures for which hourly precipitation records are available. Analogue selection was restricted either to other UK gauges or international locations with broadly similar large-scale climatological regimes, that is, west coast maritime climates at low elevation. This is illustrated graphically in Figure 1.

In this figure, the bold horizontal lines are included to identify the historical temperatures and projections for individual cities across the three time periods (2030s, 2050s and 2080s). The numbered (upper) lines indicate the range of current mean daily summer temperature for which analogues have been obtained. The hourly rainfall data from these analogue gauges were then used to estimate return period rainfall (depth-duration-frequency (DDF)) values, using peaks-over-threshold extreme value theory (Coles, 2001). The method of L-moments was used to estimate distribution parameters, as it is considered the most appropriate method for the estimation of parameters from relatively short duration records. The resultant DDF values were then compared with those for the reference gauges to derive change estimates.

It is acknowledged that uncertainty in the estimated return period rainfall totals arises for the following reasons.

- Owing to the localised nature of short, intense periods of rainfall, not all events are recorded by a relatively sparse rain gauge network. 


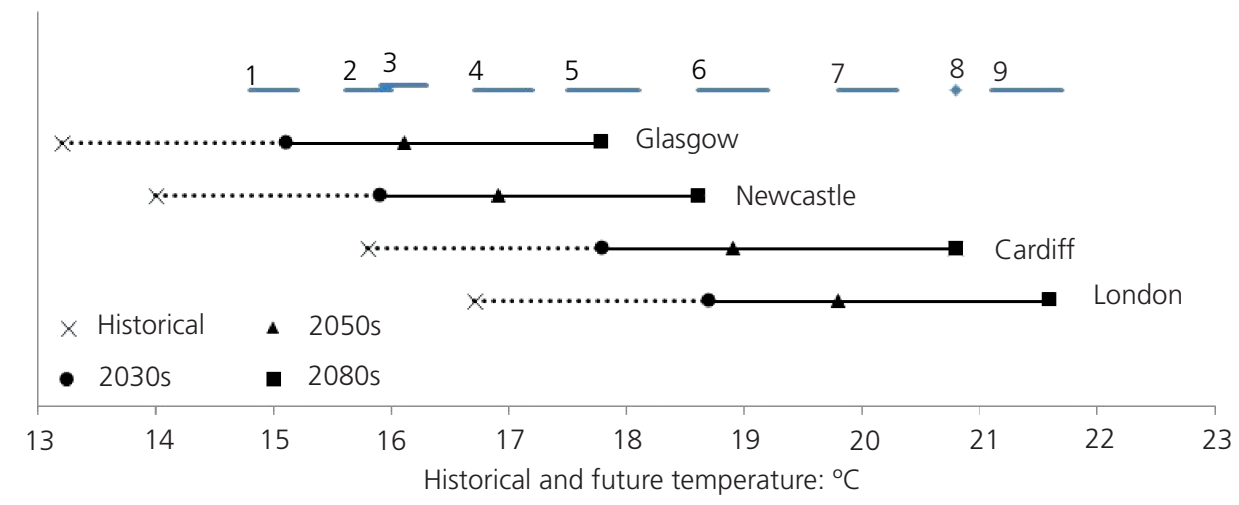

Figure 1. Range of historical and future mean daily summer temperature projections for the four UK cities. The bold horizontal lines are included to identify the historical temperatures and projections for individual cities across the three time periods (historical, 2030s, 2050s and 2080s are denoted by the black symbols). The numbered (upper) lines indicate the range of current mean daily summer temperature for which analogues have been obtained: $1=$ lowland north west 2030s; 2 = coastal north east 2030s; $3=$ lowland north west 2050s; $4=$ coastal north east 2050s; 5 = lowland north west 2080s, coastal south west 2030s; $6=$ coastal north east 2080s, coastal south west 2050s, south east 2030 s; 7 = south east 2050s; $8=$ coastal south west 2080s; $9=$ south east $2080 \mathrm{~s}$

distribution was fitted to events exceeding the $99 \cdot 5$ th percentile of non-zero hourly rainfall totals drawn from the annual record of each gauge/model simulation. The length of record here is largely dependent on the source of the data

- UK analogues: 20-30 years

- Dutch analogues: $\sim 30$ years

- French analogues: 13 years

- US analogues 20-30 years

- Convex model simulations are also of 13 years' length.

Owing to the relatively short duration of the rain gauge records and model simulations there is greater uncertainty in the estimates for longer return periods. This is particularly important when considered in combination with the inherent local nature of intense sub-daily rainfall, which is generally convective, and may result in such events not being recorded by a relatively sparse rain gauge network.

An example of the results of the analogue approach in providing estimates of historical and analogue/future return period estimates is shown in Figure 2.

\subsection{High-resolution climate modelling approach}

As part of the Natural Environment Research Council-funded Convex (convective extremes; see Convex (2015) for project details and outputs) project, the Met Office has run a RCM with a higher resolution than used previously to examine future rainfall change - using $1.5 \mathrm{~km}$ grid boxes instead of the usual $12 \mathrm{~km}$ or larger (Kendon et al., 2012) - the same as their weather forecast model. This allows convection to be represented as a dynamic process rather than using a simpler parameterisation scheme, and the model has been demonstrated to provide a more realistic representation of hourly rainfall (see e.g. Chan et al., 2013, 2014a; 


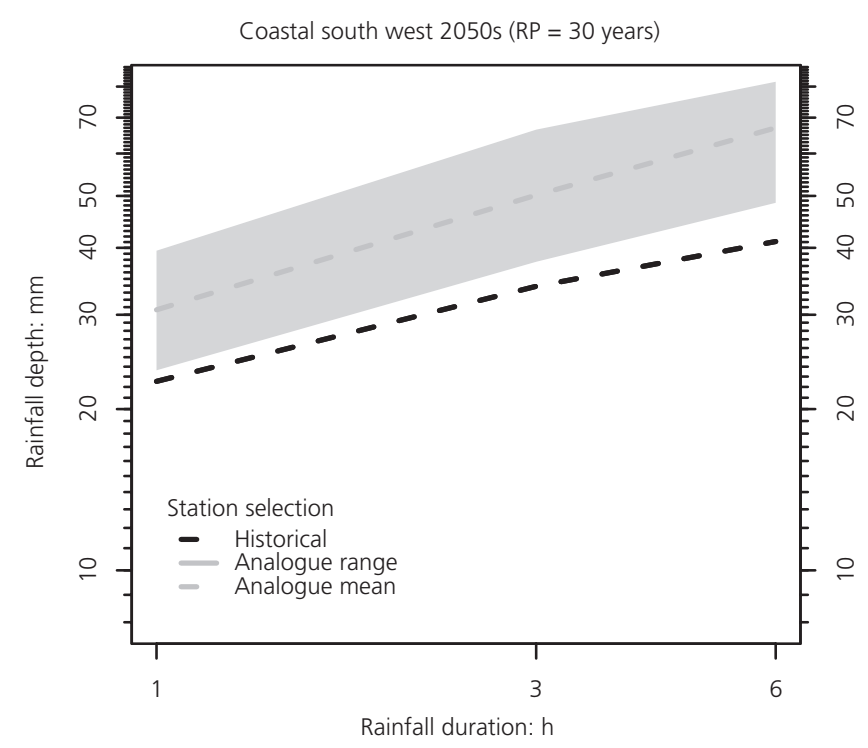

Figure 2. Return period estimates (RP) from analogue approach for one location (south-west England) for the 2050s - 30-year return period result

Kendon et al., 2012), allowing future projections to be made with improved confidence (Chan et al., 2014b; Kendon et al., 2014). A climate change experiment including a control simulation for the period from 1996 to 2009 (broadly corresponding with the climate analogue rain gauge records) was run as part of the project, whereas the future simulation provides projected climate data for the end of the twenty-first century under the Intergovernmental

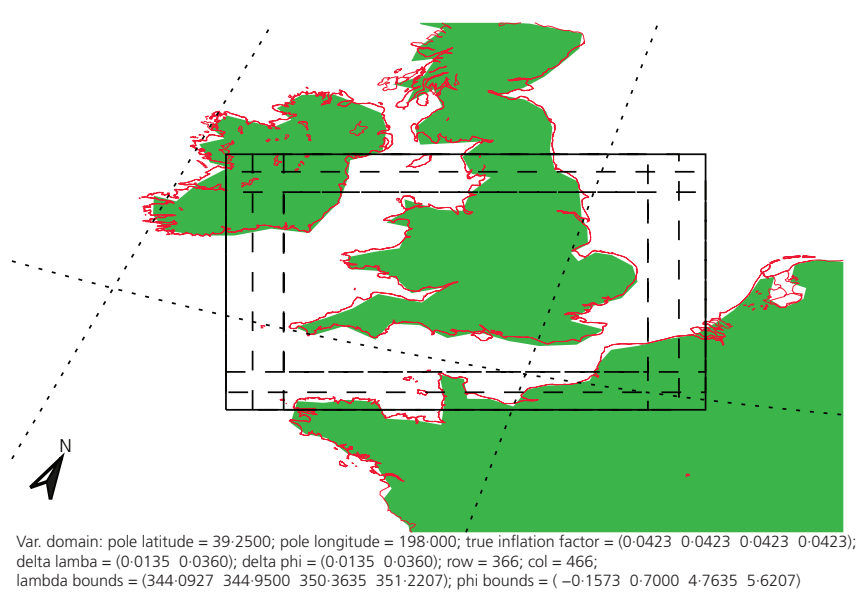

Figure 3. Convex RCM domain - the inner rectangle is the limit of the $1.5 \mathrm{~km}$ resolution area; the zone between the outer and inner rectangles is a zone of transition between $1.5 \mathrm{~km}$ and $4 \mathrm{~km}$ resolution. Boundary conditions from the $25 \mathrm{~km}$ resolution RCM are applied to the $4 \mathrm{~km}$ outer rim. The width of the inner domain (smallest dashed rectangle) is $601.5 \mathrm{~km}$ (corresponding to $401 \times 1.5 \mathrm{~km}\left(0.0135^{\circ}\right)$ grid cells $)$
Panel on Climate Change RCP $8 \cdot 5$ scenario (Collins et al., 2013). The Convex model domain comprises the southern UK, as shown in Figure 3.

Hourly precipitation data from the Convex simulations were extracted for four $3 \times 3$ matrices of cells centred on the two southern UK locations used in the climate analogue approach and on two locations at the northernmost limits of the model domain, centred near Liverpool in the north west and Grimsby in the north east. In each case, care was taken to avoid grid squares that lay over sea and also, in the case of the northern limits of the model, that these were not adjacent to the model boundary to avoid boundary effects. Return period estimates of rainfall intensities for the control and future runs were derived from these data using the same method as for the climate analogue approach. The results of these rain gauge data DDF statistics are plotted in Figure 4.

An examination of these results proved that it is not possible to identify significant regional differences between results for the four nine-cell areas across durations $(1,3$ and $6 \mathrm{~h}$ ) or return periods of 2, 5, 10 and 30 years. Given the lack of a robust basis with which to comment on regional spatial patterns of variability and the large local spatial variability in the return period estimates at the grid cell scale, a single set of Convex model-derived rainfall uplift factors across all locations has been produced. For the two northern locations used in the climate analogue approach (Glasgow and Newcastle), which are outside the Convex model domain, the assumption was made that the same changes would apply in this region, although the authors have no model data at present with which to test the validity of this assumption.

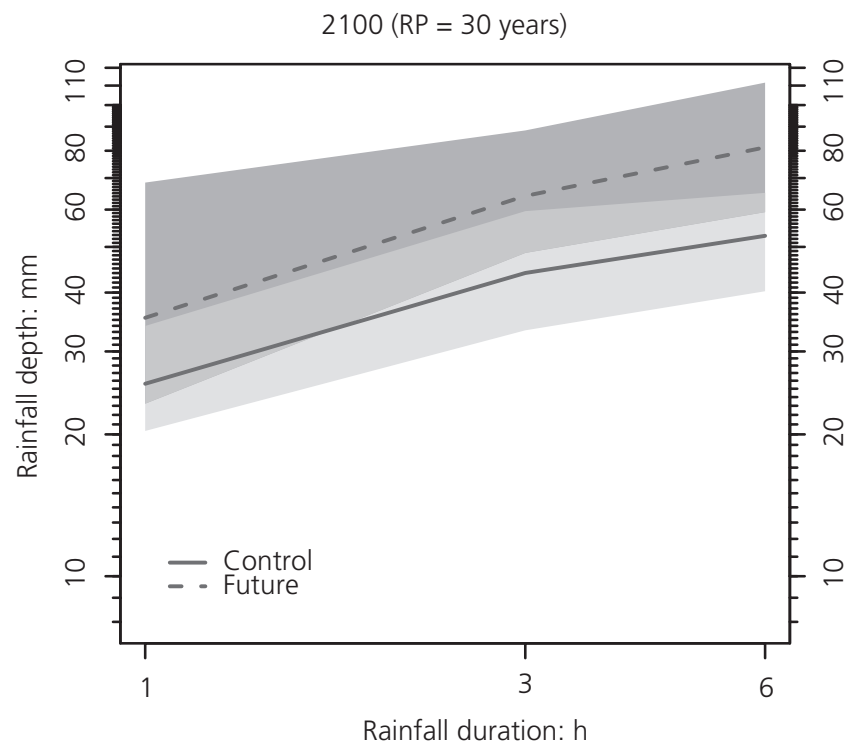

Figure 4. Results of Convex model analysis, showing rainfall depths estimated for the control/current climate (light grey band) and for the future (2100) climate (dark grey band) for 30-year return period events 


\section{Deriving rainfall intensity change estimates by combining the two approaches}

The results from the two approaches were then combined to produce uplift values applicable to all four regions of the UK for different durations and different epochs. These are presented in Table 1. To derive the uplift values for each epoch of the 2030s, 2050 s and 2080s, estimated uplifts for the analogue approach were combined with those from the high-resolution modelling approach, and the mean value from the two approaches was derived. This produced the 'central' estimate, as detailed below.

Mean \% change in rainfall depth (analogue) + mean $\%$ change in rainfall depth (Convex)

$$
2
$$

In the case of the very high-resolution (Convex) modelling approach, uplift values were produced for 2100 and then scaled linearly to the baseline period (1996-2009) to derive estimates for 2030, 2050 and 2080.

To account for some of the uncertainty in the return period estimates, high and low estimates of change have been calculated based on the results of the two approaches, so that some of this uncertainty may be represented in flooding impact investigations. These 'high' and 'low' estimates of change have been derived as follows
- 'high' estimate: highest mean change percentage in rainfall depth from either analogue or climate modelling approach

- 'low' estimate: lowest mean change percentage in rainfall depth from either analogue or climate modelling approach.

It should be noted that the 'high' and 'low' estimates of change are not absolute upper and lower bounds of possible change, as other sources of uncertainty exist (e.g. extrapolation of return periods from limited length datasets, climate model uncertainty, greenhouse gas emissions uncertainty, as discussed in Section 2.1.)

The results shown in Table 1 indicate that the estimates of rainfall intensity changes ('uplifts') from this analysis are greater than the existing allowances for rainfall intensity change produced by Defra (2006) and the Environment Agency (2011). Existing allowances are between $5 \%$ and $20 \%$ for the epochs used in this research (2030s to 2080s), which is generally significantly less than the change estimates shown in Table 1. However, it should be borne in mind that Defra and Environment Agency guidance is applicable to a 1961-1990 baseline climate, while these estimates are applicable to the current/recent climate (e.g. 1981-2010), and current guidance is also not designed to be applied at sub-daily rainfall durations.

\section{Modelling the rainfall change impacts}

Analysis of the impact of the projected rainfall changes on sewer flooding was made using recently calibrated sewer network models from four locations close to where the rainfall analyses

\begin{tabular}{|c|c|c|c|c|c|c|c|c|c|c|c|}
\hline \multirow[b]{3}{*}{ Location } & \multirow{3}{*}{$\begin{array}{l}\text { Water and sewerage } \\
\text { company applicability }\end{array}$} & \multirow{3}{*}{$\begin{array}{l}\text { Duration: } \\
\text { hours }\end{array}$} & \multicolumn{9}{|c|}{ Epoch } \\
\hline & & & \multicolumn{3}{|c|}{$2030 \mathrm{~s}$} & \multicolumn{3}{|c|}{$2050 \mathrm{~s}$} & \multicolumn{3}{|c|}{$2080 s$} \\
\hline & & & $\mathrm{L}$ & C & $\mathrm{H}$ & $\mathrm{L}$ & C & $\mathrm{H}$ & $\mathrm{L}$ & C & $\mathrm{H}$ \\
\hline \multirow{3}{*}{$\begin{array}{l}\text { North west } \\
\text { (Glasgow) }\end{array}$} & Scottish Water (west), & 1 & 14 & 19 & 25 & 16 & 27 & 37 & 23 & 50 & 88 \\
\hline & United Utilities, & 3 & 0 & 7 & 10 & 0 & 6 & 11 & 11 & 22 & 29 \\
\hline & Northern Ireland Water & 6 & 8 & 12 & 18 & 0 & 7 & 20 & 4 & 20 & 36 \\
\hline \multirow{3}{*}{$\begin{array}{l}\text { North east } \\
\text { (Newcastle) }\end{array}$} & Northumbrian Water, & 1 & 20 & 28 & 40 & 24 & 44 & 75 & 45 & 50 & 60 \\
\hline & Anglian Water (north), & 3 & 12 & 15 & 16 & 18 & 29 & 41 & 35 & 53 & 76 \\
\hline & $\begin{array}{l}\text { Severn Trent (north east), } \\
\text { Scottish Water (east), } \\
\text { Yorkshire Water }\end{array}$ & 6 & 5 & 7 & 10 & 8 & 17 & 30 & 33 & 51 & 75 \\
\hline \multirow{3}{*}{$\begin{array}{l}\text { South west } \\
\text { (Cardiff) }\end{array}$} & Dwr Cymru, South West & 1 & 15 & 38 & 76 & 27 & 29 & 34 & 15 & 26 & 32 \\
\hline & Water, Wessex Water, & 3 & 9 & 25 & 51 & 22 & 38 & 62 & 34 & 41 & 49 \\
\hline & Severn Trent (south west) & 6 & 6 & 19 & 38 & 31 & 48 & 71 & 29 & 51 & 68 \\
\hline \multirow{3}{*}{$\begin{array}{l}\text { South east } \\
\text { (London) }\end{array}$} & Thames Water, & 1 & 0 & 7 & 21 & 0 & 11 & 25 & 37 & 48 & 62 \\
\hline & Southern Water, & 3 & 0 & 8 & 15 & 25 & 27 & 31 & 42 & 45 & 50 \\
\hline & Anglian Water (south) & 6 & 19 & 22 & 28 & 44 & 54 & 74 & 51 & 65 & 84 \\
\hline
\end{tabular}

Table 1. Low (L), central (C) and high ( $\mathrm{H})$ change estimates/ 'uplifts' (\% difference in rainfall depth) derived from combining the two approaches in estimating rainfall intensity change.
Derivation of $\mathrm{L}, \mathrm{C}$ and $\mathrm{H}$ is provided in the main text. Results relate to return periods from 2 to 100 years 
were carried out. Each of these models had been created using leading industry recognised hydraulic network modelling software, InfoWorks (Innovyze, 2011). The results of the flooding analysis are shown in Table 2. These were derived by using the critical design storm duration for each of the four sewer models and by applying the central change estimate values as calculated in Section 3 and shown in Table 1.

A further analysis was undertaken using time series rainfall data at hourly resolution directly from the Convex model to examine change in combined sewer overflow (CSO) frequency and volume in one coastal sewer catchment in north-west England. The authors emphasise that these time series data are only for a single location, and from a single future realisation. Thus these results should be viewed as a plausible realisation, and not a future prediction, as no assessment of modelling uncertainty is possible without additional model simulations. Results from the Convex time series analysis used to assess CSO spills are shown in Table 3.

\section{Results and discussion}

The results in Table 1 indicate that estimates of rainfall intensity changes ('uplifts') range from $7 \%$ to $65 \%$ depending on location, event duration and future epoch. Typically, the rainfall intensities increase into the future as mean daily temperature is projected to increase. However, there is a degree of spread in the results and some non-conformities. For example, the 1-h central change estimates for the Cardiff location decrease from 2030 to 2080. With increasing temperatures projected by UKCP09 from the 2030 s to 2080 s this reversed rainfall intensity trend is not expected. The explanation for this is likely to be due to the varying effect of analogue gauge selection and points to the need for more detailed analyses, including additional gauges, to corroborate the findings and add more confidence to the estimates.
The results in Table 2 show that the percentage increase in flooding volume is greater than the percentage increase in rainfall depth. If a rainfall change percentage of $40 \%$ is used, the models show a range of total flooding increase of between $52 \%$ and $142 \%$ - a magnifying effect also seen in previous studies (see e.g. Coulthard et al., 2012). The south-east Wales model is most sensitive to rainfall increases and if this model is excluded the increase in total flooding volume is between $52 \%$ and $76 \%$. The impact on flooding volumes is dependent on the amount of 'headroom' in these systems to accommodate extra flows - this is typically a complex interaction between pipe slope, time of concentration, sewer capacity and other factors.

The modelled output from the coastal sewer catchment using a single Convex precipitation time series (Table 3) indicates the following.

- On an annual basis, there is approximately a doubling in the number of spills in the future compared to current climate.

- On an annual basis, there is approximately a quadrupling in the volume of spills in the future compared to current climate.

- During the bathing season (May to September inclusive) there is a similar number of spill events in the current and future climates, but the volume of spill is approximately $75 \%$ greater in the future.

- The minimum number of spills per year in the 13-year time series increases from three to six spills and the maximum number increases from 15 to 31 spills.

- The minimum number of spills per bathing season in the 13-year time series decreases from two to no spills and the maximum number increases from 11 to 22 spills.

Again, the authors emphasise that these results are based on a single climate model realisation, and thus further high-resolution

\begin{tabular}{|c|c|c|c|c|c|c|}
\hline \multirow[b]{3}{*}{ Location } & \multicolumn{6}{|c|}{ Epoch } \\
\hline & \multicolumn{2}{|c|}{$2030 s$} & \multicolumn{2}{|c|}{$2050 s$} & \multicolumn{2}{|c|}{$2080 s$} \\
\hline & $\begin{array}{l}\text { Rainfall \% } \\
\text { change (central } \\
\text { estimate) }\end{array}$ & $\begin{array}{l}\text { Increase in } \\
\text { sewer flooding } \\
\text { volume: \% }\end{array}$ & $\begin{array}{l}\text { Rainfall \% } \\
\text { change (central } \\
\text { estimate) }\end{array}$ & $\begin{array}{l}\text { Increase in } \\
\text { sewer flooding } \\
\text { volume: \% }\end{array}$ & $\begin{array}{l}\text { Rainfall \% } \\
\text { change (central } \\
\text { estimate) }\end{array}$ & $\begin{array}{l}\text { Increase in } \\
\text { sewer flooding } \\
\text { volume: \% }\end{array}$ \\
\hline $\begin{array}{l}\text { West Scotland } \\
\text { model }\end{array}$ & 19 & 41 & 27 & 59 & 50 & 109 \\
\hline $\begin{array}{l}\text { Northumberland } \\
\text { model }\end{array}$ & 28 & 36 & 44 & 55 & 50 & 64 \\
\hline $\begin{array}{l}\text { South-east Wales } \\
\text { model }\end{array}$ & 38 & 147 & 29 & 113 & 26 & 102 \\
\hline Greater London & 7 & 11 & 11 & 16 & 48 & 72 \\
\hline
\end{tabular}

Table 2. Increase in sewer flooding volume using four sewer models, applying the central change estimate of rainfall 


\begin{tabular}{|c|c|c|c|c|c|c|c|}
\hline $\begin{array}{l}\text { No. of } \\
\text { CSO spills in } \\
\text { 13-year record } \\
\text { (annual) }\end{array}$ & $\begin{array}{l}\text { CSO spill } \\
\text { volume in } \\
\text { 13-year record: } \\
\mathrm{m}^{3} \text { (annual) }\end{array}$ & $\begin{array}{l}\text { No. of CSO spills } \\
\text { in } 13 \text {-year record } \\
\text { (May-September } \\
\text { bathing season) }\end{array}$ & $\begin{array}{l}\text { CSO spill volume in } \\
\text { 13-year record: } \mathrm{m}^{3} \\
\text { (May-September } \\
\text { bathing season) }\end{array}$ & $\begin{array}{l}\text { Max. no. } \\
\text { of CSO } \\
\text { spills/year }\end{array}$ & $\begin{array}{l}\text { Min. no. } \\
\text { of CSO } \\
\text { spills/year }\end{array}$ & $\begin{array}{l}\text { Max. no. of } \\
\text { CSO spills } \\
\text { per bathing } \\
\text { season }\end{array}$ & $\begin{array}{l}\text { Min. no. of } \\
\text { CSO spills } \\
\text { per bathing } \\
\text { season }\end{array}$ \\
\hline 132 & 1536383 & 82 & 1110870 & 15 & 3 & 11 & 2 \\
\hline 267 & 6450417 & 81 & 1829261 & 31 & 6 & 22 & 0 \\
\hline
\end{tabular}

Table 3. CSO spill results from modelling the north-west England sewer catchment using Convex time series data (nine cells) for current (1996-2009) and future (2100) simulation climates - each simulation uses hourly data run for a 13-year period. Note: a spill has been defined as a volume of $50 \mathrm{~m}^{3}$ leaving a CSO during a continual period of flow. Where spills occur within less than $2 \mathrm{~h}$ of each other these have been classed as a combined spill regional climate modelling experiments are needed to assess their robustness.

Despite these caveats it should be noted that these changes result from only a $4 \%$ increase in annual rainfall projected from current to future climate in the Convex model simulations - that is, at this location it is raining more intensely when it rains, but less often. Outside the bathing season both the number and volume of spills are greater in the future simulation (Figures 5 and 6).

In particular, for the north-west England coastal location, and for the sewer model used, there is a significant increase in spill events occurring in the future during October. A detailed analysis, particularly on a seasonal and monthly basis, would be needed to understand these findings fully. As the north west of England's coastal climate is less prone to summer thunderstorms (intense convective, localised events) than other parts of the UK, such as south-east England (Holt et al., 2001; NERC, 1999), and rainfall patterns are typically driven more by frontal systems from the Atlantic, this aspect may partially explain the notable increase in spill events in the cooler autumn and winter months compared to the more modest increases in the current bathing season. The finding could also be due to an extension of the 'convective season' (typically May to September) in the future UK climate, in which warmer Octobers are shown in projections.

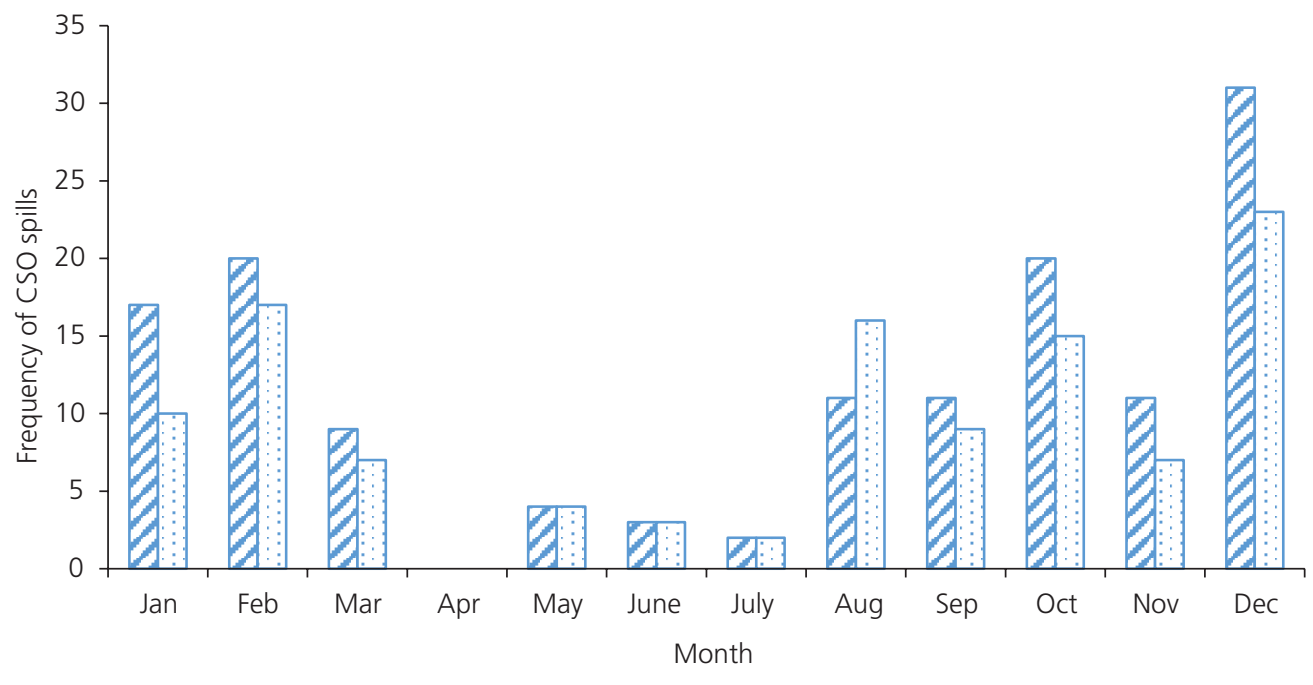

$\square$ Future frequency $\quad \square$ Current frequency

Figure 5. Frequency of CSO spills $\left(>50 \mathrm{~m}^{3}\right)$ per month for the north-west coastal sewer catchment - comparison using current and future climate rainfall data from Convex 


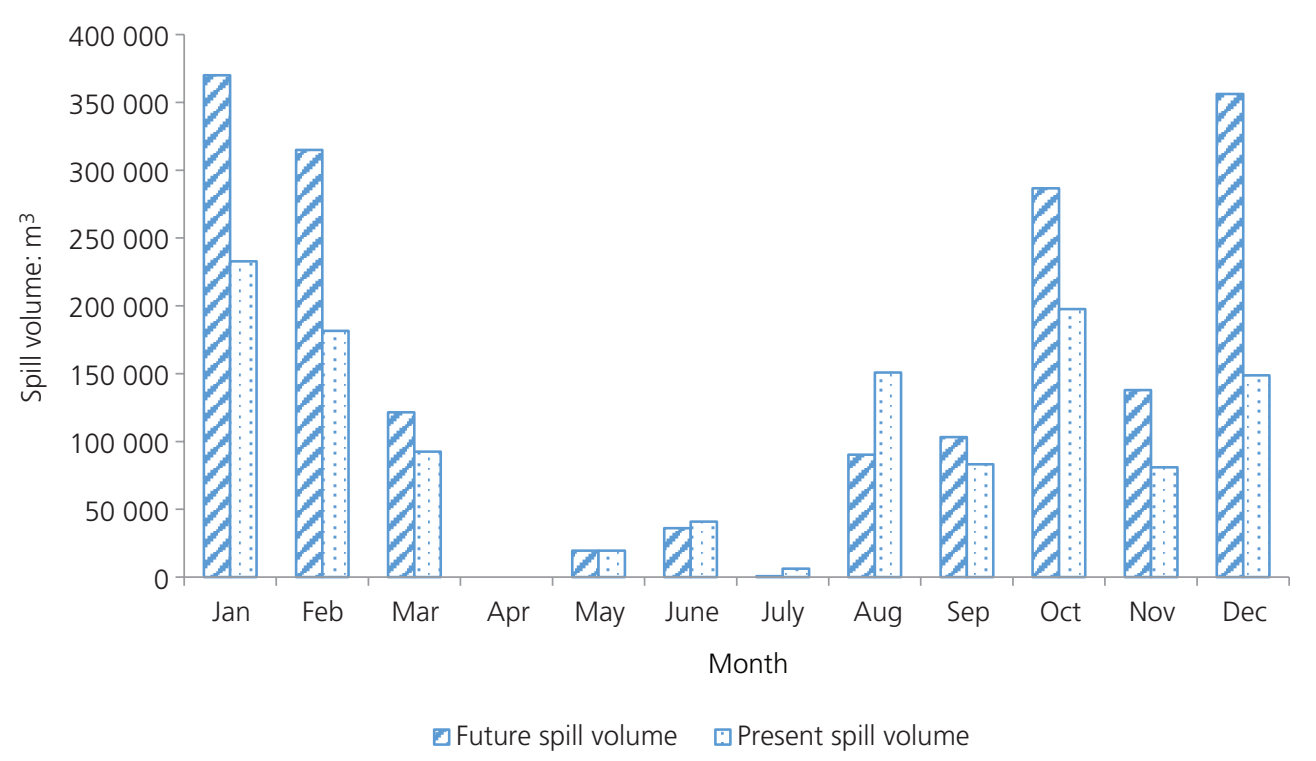

Figure 6. CSO spill volume per month for the north-west coastal sewer catchment - comparison using current and future climate rainfall data from Convex

The results point to the need for a wider and more comprehensive investigation into CSO spill frequencies and volumes around the UK and with more very high-resolution climate model data. This would enable the patterns of change to be examined on a regional basis and for a range of different sewer models.

\section{Implications for the UK water industry}

\subsection{Sewer flooding}

Although practices differ slightly across water companies the standard of service for flooding, due to hydraulic overloading, provided by new build and upgraded sewerage is typically 1 in 30 years; that is, infrastructure is designed to accommodate the current 1 in 30-year rainfall event of a critical duration. In this section a summary is provided of the adequacy of current infrastructure designed to the 1 in 30-year standard in the climate predicted for the 2030s. Table 4 summarises an analysis for the four drainage systems modelled. As shown in Table 1, these locations can be considered as broadly representative of UK water and sewerage companies across the UK. For example, for the north-west UK location, the M30-60 (30-year return period, 60-min duration) event is uplifted by $19 \%$ for the 2030 s. In this location it is necessary to design now for the 1 in 60-year event (M60-60) if a standard of service of 1 in 30 years is required in the future, but if a 1 in 30-year design is used now it will provide a reduced standard of protection of only 1 in 18 years by the 2030 s.

The results indicate that if urban drainage systems are left untouched, water customers and communities will experience an increased frequency of sewer flooding in the coming decades because of climate effects alone. This analysis adds to the body of evidence (e.g. Cettner et al., 2014) pointing to the limitations of traditional piped, sub-surface drainage systems. Available responses to water utilities include constructing larger sewers and storage structures; a response that will be expensive and relatively unadaptive to climate changes in excess of those designed for. Alternative responses include managing stormwater to delay or reduce its impact on underground storage networks by using, for example, green infrastructure such as sustainable drainage systems (Digman et al., 2012) or designing for exceedance approaches (Digman et al., 2014). These alternatives have the benefit of being more flexible in light of the considerable uncertainty surrounding climate change predictions and also introduce a range of 'nonwater' benefits to society (EPA, 2013)

\subsection{Wet weather pollution through CSOs}

CSOs operate in wet weather and are likely to operate more frequently and with greater volume in the future projected by the Convex rainfall data. CSOs are controlled to reduce spills so that a certain water quality outcome is maintained or achieved. Often, a spill frequency standard is required, whether on an annual basis (e.g. ten spills per year on average to protect shellfisheries) or seasonal basis (e.g. three spills per bathing season on average to protect bathing waters).

The results for the single location modelled indicate that significantly increased storage provision (or use of stormwater management strategies) will be required to maintain spill frequency outcomes performance and, most probably, environmental water quality outcomes in the coming decades. As with sewer flooding, the challenge for water utilities is to respond to this challenge with an affordable and effective blend of conventional (usually grey infrastructure) and innovative (increasingly green infrastructure) solutions (Gill and Shipman, 2013). 
Percentage uplift on

current 1-h duration event
Current design storm equivalent to 2030s M30-60 2030s flood likelihood of infrastructure designed to current M30-60

\begin{tabular}{lrrr}
\hline North west (Glasgow) & 19 & M60-60 & 1 in 18 years \\
North east (Newcastle) & 28 & M80-60 & 1 in 17 years \\
South west (Cardiff) & 38 & M90-60 & 1 in 10 years \\
South east (London) & 7 & M38-60 & 1 in 22 years
\end{tabular}

Table 4. Consequences of climate change for sewerage design and performance with 2030s climate

\section{Conclusions and further research}

This paper reports on two approaches, using climate analogues and a very high-resolution dynamic climate model, for estimating changes in UK rainfall intensities at short durations (1, 3 and $6 \mathrm{~h}$ ) as a result of climate change. The current generation of relatively coarse resolution climate models such as those used in UKCP09 do not adequately represent intense summer convective rainfall events, although they provide reasonable estimates of change in winter rainfall intensities. This innovative dynamic modelling provides increased confidence in projections of change for UK rainfall intensities at hourly durations, particularly for summer. Mean values of the rainfall estimates derived from these approaches have been used to estimate potential flooding and sewer pollution impact using sewer models provided by participating UK water companies.

The new estimates of rainfall intensity change produced in this research are, in general, higher than existing UK climate change allowances for rainfall intensity. In combination with the rainfall and sewer modelling results presented, this research suggests that significantly increased storage provision (either through grey or green infrastructure) will be required to manage sewer flooding, maintain spill frequency outcomes and, most probably, environmental water quality outcomes.

It should be noted there is considerable uncertainty associated with the size of the future increase in hourly rainfall intensity. In particular, the high-resolution modelling results here are based on a single future realisation from one climate model, and thus can be considered a plausible outcome but not a prediction. Further high-resolution climate model experiments are needed to allow an assessment to be made of the robustness of these findings.

Further research and access to/analysis of increased quantities of data would benefit the water industry in the following ways

v increasing confidence in the estimates of future rainfall intensity changes

- increasing confidence in assessments for the locations in the UK that are currently outside the Convex model domain (northern England, Northern Ireland and Scotland)

- examining the impact of very high-resolution climate model rainfall data time series in other locations in order to derive criteria by which to adjust historic rainfall time series so that they are representative of future time series rainfall data.

\section{Acknowledgements}

The authors acknowledge UK Water industry Research for funding the research on which this paper is based. The high-resolution $(1.5 \mathrm{~km})$ model results were provided by the UK Met Office as part of the Convex project (UK NERC Changing Water Cycle programme grant: NE/I006680/1) and the UKMO Hadley Centre research programme, supported by the Joint Department of Energy and Climate Change and Department for Environment, Food and Rural Affairs (grant: GA01101). Hayley J. Fowler is funded by the Wolfson Foundation and the Royal Society as a Royal Society Wolfson Research Merit Award (WM140025) holder.

\section{REFERENCES}

Arnbjerg-Nielsen K, Willems P, Olsson J et al. (2013) Impacts of climate change on rainfall extremes and urban drainage systems: a review. Water Science and Technology 68(1): 16-28.

Ashley RM, Balmforth DJ, Saul AJ and Blanksby JD (2005) Flooding in the future - predicting climate change, risks and responses in urban areas. Water Science and Technology 55(5): 265-273.

Ashley RM, Tait SJ, Styan E et al. (2007) Sewer system design moving into the 21 st century - a UK perspective. Water Science and Technology 55(4): 273-281.

Berggren K (2014) Urban Stormwater Systems in Future Climates - Assessment and Management of Hydraulic Overloading. Doctoral thesis, Lulea University of Technology, Lulea, Sweden. Blenkinsop S, Chan SC, Kendon EJ, Roberts NM and Fowler HJ (2015) Temperature influences on intense UK hourly precipitation and dependency on large-scale circulation. Environmental Research Letters 10(5): 054021, http://dx.doi. org/10.1088/1748-9326/10/5/054021.

Cabinet Office (2008) The Pitt Review - Learning Lessons from the 2007 Floods. Cabinet Office, London, UK.

Cettner A, Ashley R, Hedström A and Viklander M (2014) Sustainable development and urban stormwater practice. Urban Water Journal 11(3): 185-197.

Chan SC, Kendon EK, Fowler HJ et al. (2013) Does increasing the spatial resolution of a regional climate model improve the simulated daily precipitation? Climate Dynamics 41(5-6): 1475-1495. 
Chan SC, Kendon EK, Fowler HJ et al. (2014a) The value of high-resolution Met Office regional climate models in the simulation of multi-hourly precipitation extremes. Journal of Climate 27(16): 6155-6174.

Chan SC, Kendon EJ, Fowler HJ, Blenkinsop S and Roberts NM (2014b) Projected increases in summer and winter UK sub-daily precipitation extremes from high-resolution regional climate models. Environmental Research Letters

9(8): 084019, http://dx.doi.org/10.1088/1748-9326/9/8/084019.

Coles S (2001) An Introduction to Statistical Modeling of Extreme Values. Springer, London, UK.

Collins M, Knutti R, Arblaster J et al. (2013) Long-term climate change: projections, commitments and irreversibility. Climate Change 2013: The Physical Science Basis. Contribution of Working Group I to the Fifth Assessment Report of the Intergovernmental Panel on Climate Change (Stocker TF, Qin D, Plattner GK et al. (eds)). Cambridge University Press, Cambridge, United Kingdom and New York, NY, USA.

Convex (2015) Using Observational Evidence and Process Understanding to Improve Predictions of Extreme Rainfall Change. University of Newcastle, Newcastle upon Tyne, UK. See http://research.ncl.ac.uk/convex/ (accessed 15/08/2015).

Coulthard TJ, Ramirez J, Fowler HJ and Glenis V (2012) Using the UKCP09 probabilistic scenarios to model the amplified impact of climate change on drainage basin sediment yield. Hydrology and Earth System Sciences 16(11): 4401-4416, http://dx.doi. org/10.5194/hess-16-4401-2012.

Davies P (2010) Understanding changing weather patterns. Proceedings of the CIWEM National Conference on Surface Water Management. SOAS, London, UK. See http://www.ciwem.org/events/events-outputs.aspx (accessed 24/08/2015).

Defra (Department for Environment, Food and Rural Affairs) (2006) Flood and Coastal Defence Appraisal Guidance FCDPAG3 Economic Appraisal - Supplementary Note to Operating Authorities - Climate Change Impacts. Defra, London, UK.

Digman CJ, Ashley RM, Balmforth DJ, Stovin DW and Glerum JW (2012) Retrofitting to Manage Surface Water. Ciria, London, UK, RP922.

Digman CJ, Ashley RM, Hargreaves P and Gill E (2014) Managing Urban Flooding from Heavy Rainfall - Encouraging the Uptake of Designing for Exceedance - Recommendations and Summary. Ciria, London, UK, C738a.

Environment Agency (2011) Adapting to Climate Change: Advice for Flood and Coastal Erosion Risk Management Authorities. Environment Agency, London, UK.

EPA (US Environmental Protection Agency) (2013) Case Studies Analyzing the Economic Benefits of Low Impact Development and Green Infrastructure Programs. US Environmental Protection Agency, Office of Wetlands, Oceans and Watersheds, Nonpoint Source Control Branch (4503T), Washington, DC, USA, EPA 841-R-13-004.

Flato G, Marotzke J, Abiodun B et al. (2013) Evaluation of climate models. Climate Change 2013: The Physical Science
Basis. Contribution of Working Group I to the Fifth Assessment Report of the Intergovernmental Panel on Climate Change (Stocker TF, Qin D, Plattner GK et al. (eds)). Cambridge University Press, Cambridge, UK and New York, NY, USA.

Fowler HJ and Ekström M (2009) Multi-model ensemble estimates of climate change impacts on UK seasonal precipitation extremes. International Journal of Climatology 29: $385-416$.

Gill EJ and Shipman E (2013) Framework for developing a stormwater management business case. UKWIR, London, UK, $\mathrm{SW} / 01$

Hand W (2002) A Historical Study of Extreme Events in the 20th Century. Met Office Forecasting Research, London, UK, Technical Report No. 384.

Hanel M and Buishand TA (2010) On the value of hourly precipitation extremes in regional climate model simulations. Journal of Hydrology 393: 265-273.

Hardwick Jones R, Westra SP and Sharma A (2010) Observed relationships between extreme sub-daily precipitation, surface temperature, and relative humidity. Geophysical Research Letters 37: L22805, http://dx.doi.org/10.1029/2010GL045081. Holt MA, Hardaker PJ and McLelland GP (2001) A lightning climatology for Europe and the UK, 1990-99. Weather 56(9): 290-296.

Innovyze (2011) Innovyze InfoWorks CS (Collection Systems) Technical Review. See http://www.innovyze.com/products/ infoworks_cs/ (accessed 13/4/2015).

IPCC (2000) Emissions Scenarios (Nakicenovic N and Swart R (eds)). Cambridge University Press, Cambridge, UK.

Kendon EJ, Roberts NM, Senior CA and Roberts MJ (2012) Realism of rainfall in a very high resolution regional climate model. Journal of Climate 25(17): 5791-5806.

Kendon EJ, Roberts NM, Fowler HJ et al. (2014) Heavier summer downpours with climate change revealed by weather forecast resolution model. Nature Climate Change 4: 570-576, http://dx.doi.org/10.1038/nclimate2258.

Lenderink G and van Meijgaard E (2008) Increase in hourly precipitation extremes beyond expectations from temperature changes. Nature Geoscience 1: 511-514, http://dx.doi.org/ $10.1038 /$ ngeo 262 .

Met Office (2010) Changes in the Frequency of Extreme Rainfall Events for selected Towns and Cities. Met Office, Exeter, UK, report produced for Ofwat. See http://www.ofwat.gov.uk/ sustainability/climatechange/rpt_com_met_rainfall.pdf (accessed 28/08/2014).

Mott MacDonald (2011) Future Impacts on Sewer Systems in England and Wales. Mott MacDonald, Report produced for Ofwat, Cambridge, UK.

Murphy JM, Sexton DMH, Jenkins GJ et al. (2009) UK Climate Projections Science Report: Climate Change Projections. Met Office, Hadley Centre, Exeter, UK.

NERC (Natural Environment Research Council) (1999) The Flood Estimation Handbook. NERC, Swindon, UK, vol. 1, Rainfall. 
Smith L, Liang Q, James P and Lin W (2015) Assessing the utility of social media as a data source for flood risk management using a real-time modelling framework. Journal of Flood Risk Management, http://dx.doi.org/10.1111/jfr3.12154.

Trenberth KE, Dai RM, Rasmussen RM and Parsons DB (2003) The changing character of precipitation. Bulletin of the American Meteorological Society 84: 1205-1217.

UKWIR (UK Water Industry Research) (2003) Climate Change and the Hydraulic Design of Sewerage Systems - Volume I: Climate Change Effects on Rainfall; IA - Climate Change and the Production of FSR, FEH and Year 2080 Rainfall Maps. UKWIR, London, UK, Ref. 03/CL/10/1.

UKWIR (2011) Climate Change Modelling for Sewerage Networks. UKWIR, London, UK, Ref. 10/CL/10/15. UKWIR (2015) Rainfall Intensity for Sewer Design. UKWIR, London, UK, Ref. 15/CL/10/16.

Utsumi NS, Seto S, Kanae S, Maeda EE and Oki T (2011) Does higher surface temperature intensify extreme precipitation? Geophysical Research Letters 38: L16708, http://dx.doi.org/ 10.1029/2011GL048426.
WHAT DO YOU THINK?

To discuss this paper, please submit up to 500 words to the editor at journals@ice.org.uk. Your contribution will be forwarded to the author(s) for a reply and, if considered appropriate by the editorial panel, will be published as a discussion in a future issue of the journal.

Proceedings journals rely entirely on contributions sent in by civil engineering professionals, academics and students. Papers should be 2000-5000 words long (briefing papers should be 1000-2000 words long), with adequate illustrations and references. You can submit your paper online via www.icevirtuallibrary.com/content/journals, where you will also find detailed author guidelines. 